\title{
Effects of Surrounding Environment and Management System in Apple Orchards on the Occurrence of Ground Beetles
}

\author{
Elżbieta Wojciechowicz-Żytko*, Edyta Wilk \\ Department of Plant Protection, Faculty of Biotechnology and Horticulture, \\ University of Agriculture, Kraków, Poland
}

Received: 6 June 2018

Accepted: 7 August 2018

\begin{abstract}
The aim of the observations was to determine the species composition of the Carabidae occurring in apple orchards with integrated and organic pest management, and to determine the impact of the surrounding areas on the Carabidae fauna appearing in those orchards.

A total of 367 individuals of the Carabidae, representing 17 species from 15 genera, were collected in apple orchards with different management systems and surroundings.

In both years of research, Carabidae beetles were the most numerous in the ecological orchard (142 specimens and species richness 5.8). Of the three orchards where integrated pest management was applied, the Carabidae most often occurred in the orchard with the most varied vegetation, withshrubs, trees and herbaceous plants in the neighbourhood (94 individuals). The lowest number of beetles, only 52 specimens, was reported for the site with the poorest vegetation in the neighbourhood (species richness 3.5).

The species that dominated the carabid assemblages in the orchard habitats was Harpalus rufipes, which constituted more than $60 \%$. In terms of the number of specimens, the hemizoophages constituted the dominant group among the collected Carabidae, and the highest number was found in the ecological orchard.

The presence of refuge sites contributed to the increase in species richness of the Carabidae, whereas the use of chemical treatments in the IPM apple orchards negatively affected species richness and the number of carabids.
\end{abstract}

Keywords: carabids, apple orchards, IPM, organic, neighbouring areas

*e-mail: ewojcie@ogr.ar.krakow.pl 


\section{Introduction}

Ground beetles of the Carabidae family are considered useful entomofauna since they are natural enemies of many pests and help regulate the numbers of harmful insects, which results in providing environmental resistance to phytophagous insects [1-4]. The Carabidae are often used in studies monitoring the environment and are called bioindicators. On the basis of their occurrence, the state of degradation or development of habitats can be determined [5-8].

As a result of agricultural intensification, particularly over large areas and with limited crop rotation, a significant reduction in biodiversity is observed [4]. The land and crop management systems usually have a strong influence on the abundance and diversity of arthropods. Apple orchards are under intense chemical pest and disease control. The side effects of the use of pesticides on ground-dwelling predators such as carabids may be direct through mortality or lower fecundity, or indirect through a reduction in the biomass of their prey [9]. When orchards with different chemical treatments are compared, the biodiversity and abundance of the Carabidae are generally lower in the orchards managed with broad spectrum insecticides [1012]. Other management aspects such as groundcover or the biodiversity of neighbouring areas also have an impact on carabids $[9,10]$.

The aim of the observations was to determine the species composition of the Carabidae occurring in apple orchards with integrated and organic pest management, and to determine the impact of the surrounding areas on the Carabidae fauna appearing in those orchards.

\section{Materials and Methods}

\section{Research Sites}

The observations were carried out in 2012-2013 in southeastern Poland, near Przemyśl $\left(49.82^{\circ} \mathrm{N}\right.$, $22.79^{\circ} \mathrm{E}$ ) in three apple orchards where integrated pest management (IPM) was applied (sites I-III, area of 9, $10,8.5$ ha, respectively), and in one organic (ecological) apple orchard (site IV, 9 ha) with 'Szampion,' 'Elise' and 'Elstar' cultivars. The neighbouring areas of the orchards consisted of: site I - woodlands, shrubs and herbaceous plants; site II - a pear orchard and herbaceous plants; site III - a pear orchard, woodlands with a predominance of spruce and herbaceous plants; site IV - a walnut orchard and herbaceous plants. Plant habitat in surroundings of apple orchards is shown in Table 1.

No chemicals were used in the ecological orchard, while the plants in the IPM orchards were conducted in accordance with the methodology of integrated production.
Table 1. Plant habitats in apple orchard surroundings.

\begin{tabular}{|c|c|c|c|c|}
\hline Plant species/genera & $\begin{array}{c}\text { Site } \\
\text { I }\end{array}$ & $\begin{array}{c}\text { Site } \\
\text { II }\end{array}$ & $\begin{array}{l}\text { Site } \\
\text { III }\end{array}$ & $\begin{array}{l}\text { Site } \\
\text { IV }\end{array}$ \\
\hline \multicolumn{5}{|l|}{ trees } \\
\hline Cerasus vulgaris Mill. & + & & + & \\
\hline Juglans regia $\mathrm{L}$. & + & & & + \\
\hline Picea abies (L.) & + & & + & \\
\hline Prunus avium $\mathrm{L}$. & + & & + & \\
\hline Prunus domestica $\mathrm{L}$. & + & & + & \\
\hline Pyrus L. & & + & + & \\
\hline Rhus typhina $\mathrm{L}$. & + & & + & \\
\hline \multicolumn{5}{|c|}{ shrubs } \\
\hline Berberis vulgaris L. & + & & + & \\
\hline Buxus sempervirens L. & + & & & \\
\hline Corylus avellana $\mathrm{L}$. & + & & + & \\
\hline Crataegus monogyna Jacq. & + & & & \\
\hline Ligustrum vulgare $\mathrm{L}$. & + & & + & \\
\hline Photinia melanocarpa Michx. & + & & & \\
\hline Ribes uva-crispa L. & + & & & \\
\hline Ribes L. & + & & & \\
\hline Rosa canina $\mathrm{L}$. & + & & & + \\
\hline Rubus L. & + & & & + \\
\hline Sambucus nigra L. & + & & & + \\
\hline Syringa vulgaris L. & + & & + & \\
\hline \multicolumn{5}{|c|}{ herbaceous plants } \\
\hline Achillea millefolium $\mathrm{L}$. & + & + & & + \\
\hline Aegopodium podagraria L. & + & + & + & + \\
\hline Artemisia absinthium L. & + & & & + \\
\hline Atriplex L. & + & & & + \\
\hline Capsella bursa-pastoris $\mathrm{L}$. & + & + & & + \\
\hline Daucus carota $\mathrm{L}$. & + & + & + & \\
\hline Galinsoga parviflora Cav. & + & + & & + \\
\hline Galium aparine L. & + & + & & + \\
\hline Lamium album $\mathrm{L}$ & + & + & + & + \\
\hline Lamium purpureum L. & + & + & + & \\
\hline Matricaria discoidea DC. & + & + & & + \\
\hline Plantago lanceolata L. & + & + & + & + \\
\hline Poa annua $\mathrm{L}$. & & & & + \\
\hline Ranunculus acris L. & + & + & + & \\
\hline Rhamnus cathartica L. & + & & + & \\
\hline Rumex acetosa $\mathrm{L}$. & + & + & & + \\
\hline Stellaria media (L.) Vill. & + & + & + & + \\
\hline
\end{tabular}


Table 1. Continued.

\begin{tabular}{|c|c|c|c|c|}
\hline Solidago virgaurea L. & + & + & & + \\
\hline Taraxacum officinale Web. & + & + & + & + \\
\hline Trifolium repens L. & + & + & + & + \\
\hline Urtica dioica L. & + & + & + & + \\
\hline Urtica urens L. & + & + & & + \\
\hline Veronica chamaedrys L. & + & + & + & + \\
\hline
\end{tabular}

\section{Carabid Sampling}

Surface-active carabids were collected using modified covered Barber pitfall traps. Each trap consisted of a plastic jar $10 \mathrm{~cm}$ in diameter and $300 \mathrm{~cm}^{2}$ in size, half-filled with $25 \%$ ethylene glycol to kill and preserve the trapped insects, and set into the ground up to its upper edge [13]. A small roof was installed above each trap to prevent rainwater from flowing into the jar, diluting the solution and causing the trap to overflow. Three traps in a row between trees, set $10 \mathrm{~m}$ from one another, were placed in each of the experimental orchards. Samples were collected from the beginning of May until mid-August every 14 days, when the preserving solution was supplemented and the beetles from the traps were transferred into $75 \%$ ethanol.

The identification of the collected carabids was based on key [14], using the terminology proposed by Stachowiak [14].

The captured Carabidae individuals were then analysed with respect to species composition, abundance, dominance structure and frequency.

\section{Statistical Analysis}

In order to verify the differences between carabid assemblages, 2-way (surrounding neighbourhood, production system) analysis of variance ANOVA (Statistica version 10.0) was used. Post-hoc multiple comparisons were made by Tukey's Honestly Significant Difference (HSD) test with the level of significance at $\mathrm{p}<0.05$.

\section{Results}

The species composition of the carabids collected on the ground of the investigated apple orchards is shown in Table 2. During the observations, 367 individuals belonging to 17 species from 15 genera were found. Considerably more beetles were caught in 2012 than in 2013 (222 and 145, respectively). The number of the collected species ranged from 7 on site II (IPM apple orchard surrounded by a pear orchard and herbaceous plants) to 13 on site IV (organic apple orchard surrounded by a walnut orchard and herbaceous plants) (Table 2).
There were significant differences in the number of beetles occurring on the various sites. In both years of research, the Carabidae were the most numerous on site IV (ecological orchard). In this orchard, no chemical treatments were used. Of the three orchards where integrated pest management was applied, the Carabidae most often occurred in the orchard with the most varied vegetation in the neighbourhood - site I. The presence of trees and shrubs with herbaceous vegetation provides an ideal living place for the beetles. The obtained results confirm the rule according to which the diversity of habitats is connected with an increase in the number of species, which often occurs as recedents and subrecedents increase biodiversity.

However, in the apple orchard on site I some pesticides were used (according to the methodology of integrated production), which could have contributed to a smaller number of beetles in relation to site IV (organic orchard) (Table 2). The lowest number of beetles was reported for site II, with the poorest vegetation in the neighbourhood.

The species that dominated the carabid assemblages in the orchard habitats was Harpalus rufipes - which constituted more than $70 \%$ on site II and about $60 \%$ on sites I, III and IV (Table 2). It was classified as eudominants. The genus Amara on sites I and IV and the species Pterostichus melanarius on site III were also eudominants. On the other sites, this species was classified to subdominants (sites I and IV) or recedents (site II) (Table 2).

It can be concluded that on site I (IPM orchard) -5 species (Nebria brevicollis, Poecilus cupreus, Harpalus affinis, Anisodactylus binotatus, A. signatus) and 2 genera (Harpalus, Ophonus) belonged to the class of subrecedents, on site IV (organic orchard) - 5 species (Diachromus germanus, H. affinis, Zabrus tenebrioides, Anchomenus dorsalis, Carabus granulatus) and 1 genus (Harpalus) were also subrecedents, whereas on sites II and III there were no subrecedents (Table 2).

The frequency of the Carabidae on the different sites varied. The most numerous was H. rufipes, and the frequency ranged from $33 \%$ to $37 \%$, which means that this species was recorded in more than one-third of the collected samples. The genus Amara occurred in large numbers on sites I and IV, where it was recorded in a quarter of the samples, while on the remaining sites its frequency was low (Table 2). Some species, e.g., Carabus ulrichii, D. germanus, Dolichus halensis, and $Z$. tenebrioides were noted only in the organic orchard (site IV). In both years of observations, the largest numbers of species (10 in 2012, 9 in 2013) were found in the ecological orchard (site IV), whereas the smallest number (4) was recorded in 2012 on site II the IPM orchard with poorly diversified vegetation in the neighbourhood. Species richness on the sites ranged from 3.5 (site II) to 5.8 (site IV) (Table 3).

A similarity of over $50 \%$ was observed between sites I and III, and I and IV, while the least similar to each other were sites II and III, and II and IV (Fig. 1). 
Table 2. Species composition, domination, frequency and ecological specification of collected carabids (2012-2013).

\begin{tabular}{|c|c|c|c|c|c|c|c|c|}
\hline \multirow{2}{*}{ Species/genus } & \multicolumn{2}{|c|}{ Total } & \multirow{2}{*}{ Frequency } & \multicolumn{5}{|c|}{ Ecological specification } \\
\hline & Number & {$[\%]$} & & H.p. & F.d. & P.h. & T.d. & $\mathrm{Z}$ \\
\hline \multicolumn{9}{|c|}{ Site I } \\
\hline Harpalus rufipes (De Geer) & 57 & $60.1^{\mathrm{ED}}$ & 37.5 & $\mathrm{OA}$ & $\mathrm{Hz}$ & Mhy & S & ES \\
\hline Amara sp. & 20 & $21.2^{\mathrm{ED}}$ & 25.0 & & $\mathrm{~Hz}$ & & & \\
\hline Pterostichus niger (Schall.) & 6 & $6.5^{\mathrm{D}}$ & 16.6 & $\mathrm{~F}$ & $\mathrm{Lz}$ & Mhy & A & ES \\
\hline Pterostichus melanarius (Ill.) & 4 & $4.2^{\mathrm{SD}}$ & 8.3 & $\mathrm{Eu}$ & $\mathrm{Lz}$ & Mhy & S & ES \\
\hline Nebria brevicollis (Fabr.) & 1 & $1.0^{\mathrm{SR}}$ & 4.1 & $\mathrm{~F}$ & $\mathrm{Sz}$ & Mhy & A & Ear \\
\hline Poecilus cupreus (L.) & 1 & $1.0^{\mathrm{SR}}$ & 4.1 & $\mathrm{Eu}$ & $\mathrm{Sz}$ & Mhy & $\mathrm{S}$ & $\mathrm{Pal}$ \\
\hline Harpalus affinis (Schrank) & 1 & $1.0^{\mathrm{SR}}$ & 4.1 & $\mathrm{OA}$ & $\mathrm{Hz}$ & Mhy & S & $\mathrm{Pal}$ \\
\hline Harpalus sp. & 1 & $1.0^{\mathrm{SR}}$ & 4.1 & & $\mathrm{~Hz}$ & & & \\
\hline Ophonus sp. & 1 & $1.0^{\mathrm{SR}}$ & 4.1 & & $\mathrm{~Hz}$ & & & \\
\hline Anisodactylus binotatus (Fabr.) & 1 & $1.0^{\mathrm{SR}}$ & 4.1 & $\mathrm{OA}$ & $\mathrm{Sz}$ & Mhy & $\mathrm{S}$ & $\mathrm{Pal}$ \\
\hline Anisodactylus signatus (Panz.) & 1 & $1.0^{\mathrm{SR}}$ & 4.1 & $\mathrm{~F}$ & $\mathrm{Sz}$ & Mhy & $\mathrm{S}$ & ES \\
\hline Total & 94 & 100 & & & & & & \\
\hline \multicolumn{9}{|c|}{ Site II } \\
\hline Harpalus rufipes (De Geer) & 37 & $71.2^{\mathrm{ED}}$ & 37.5 & $\mathrm{OA}$ & $\mathrm{Hz}$ & Mhy & $\mathrm{S}$ & ES \\
\hline Pterostichus melanarius (Ill.) & 1 & $1.9^{\mathrm{R}}$ & 4.1 & $\mathrm{Eu}$ & $\mathrm{Lz}$ & Mhy & $\mathrm{S}$ & ES \\
\hline Anisodactylus binotatus (Fabr.) & 3 & $5.7^{\mathrm{D}}$ & 12.5 & $\mathrm{OA}$ & $\mathrm{Sz}$ & Mhy & $\mathrm{S}$ & $\mathrm{Pal}$ \\
\hline Anisodactylus signatus (Panz.) & 4 & $7.7^{\mathrm{D}}$ & 12.5 & $\mathrm{~F}$ & $\mathrm{Sz}$ & Mhy & $\mathrm{S}$ & ES \\
\hline Badister sp. & 1 & $1.9^{\mathrm{R}}$ & 4.1 & & $\mathrm{Sz}$ & & & \\
\hline Amara sp. & 2 & $3.9^{\mathrm{SD}}$ & 8.3 & & $\mathrm{~Hz}$ & & & \\
\hline Poecilus cupreus (L.) & 2 & $3.9^{\mathrm{SD}}$ & 4.1 & $\mathrm{Eu}$ & $\mathrm{Sz}$ & Mhy & $\mathrm{S}$ & $\mathrm{Pal}$ \\
\hline Limodromus assimilis (Payk.) & 1 & $1.9^{\mathrm{R}}$ & 4.1 & $\mathrm{~F}$ & $\mathrm{Sz}$ & $\mathrm{M}$ & $\mathrm{S}$ & $\mathrm{Pal}$ \\
\hline Calathus fuscipes Goeze & 1 & $1.9^{\mathrm{R}}$ & 4.1 & $\mathrm{OA}$ & $\mathrm{Sz}$ & $\mathrm{M}$ & A & $\mathrm{Pal}$ \\
\hline Total & 52 & 100 & & & & & & \\
\hline \multicolumn{9}{|c|}{ Site III } \\
\hline Harpalus rufipes (De Geer) & 47 & $60.0^{\mathrm{ED}}$ & 37.5 & $\mathrm{OA}$ & $\mathrm{Hz}$ & Mhy & $\mathrm{S}$ & ES \\
\hline Pterostichus melanarius (Ill.) & 13 & $16.3^{\mathrm{ED}}$ & 25.0 & $\mathrm{Eu}$ & $\mathrm{Lz}$ & Mhy & $\mathrm{S}$ & ES \\
\hline Pterostichus niger (Schall.) & 3 & $3.8 \mathrm{~S}^{\mathrm{D}}$ & 12.5 & $\mathrm{~F}$ & $\mathrm{Lz}$ & Mhy & A & ES \\
\hline Carabus violaceus (L.) & 1 & $1.2^{\mathrm{R}}$ & 4.1 & $\mathrm{~F}$ & $\mathrm{Lz}$ & Mhy & $\mathrm{S}$ & $\mathrm{Pal}$ \\
\hline Nebria brevicollis (Fabr.) & 1 & $1.2^{\mathrm{R}}$ & 4.1 & $\mathrm{~F}$ & $\mathrm{Sz}$ & Mhy & A & Ear \\
\hline Harpalus affinis (Schrank) & 2 & $2.5^{\mathrm{SD}}$ & 8.3 & $\mathrm{OA}$ & $\mathrm{Hz}$ & Mhy & $\mathrm{S}$ & $\mathrm{Pal}$ \\
\hline Calathus fuscipes Goez & 1 & $1.2^{\mathrm{R}}$ & 4.1 & $\mathrm{OA}$ & $\mathrm{Sz}$ & $\mathrm{M}$ & A & Pal \\
\hline Harpalus sp. & 2 & $2.5^{\mathrm{SD}}$ & 8.3 & & $\mathrm{~Hz}$ & & & \\
\hline Amara sp. & 7 & $8.9^{\mathrm{D}}$ & 8.3 & & $\mathrm{~Hz}$ & & & \\
\hline Anisodactylus signatus (Panz.) & 1 & $1.2^{\mathrm{R}}$ & 4.1 & $\mathrm{~F}$ & $\mathrm{Sz}$ & Mhy & $\mathrm{S}$ & ES \\
\hline Limodromus assimilis (Payk.) & 1 & $1.2^{\mathrm{R}}$ & 4.1 & $\mathrm{~F}$ & $\mathrm{Sz}$ & $\mathrm{M}$ & $\mathrm{S}$ & Pal \\
\hline Total & 79 & 100 & & & & & & \\
\hline \multicolumn{9}{|c|}{ Site IV } \\
\hline Harpalus rufipes (De Geer). & 86 & $60.5^{\mathrm{ED}}$ & 33.3 & $\mathrm{OA}$ & $\mathrm{Hz}$ & Mhy & $\mathrm{S}$ & ES \\
\hline
\end{tabular}


Table 2. Continued.

\begin{tabular}{|c|c|c|c|c|c|c|c|c|}
\hline Amara sp. & 24 & $16.9^{\mathrm{ED}}$ & 20.8 & & $\mathrm{~Hz}$ & & \\
\hline Anisodactylus binotatus (Fabr.) & 6 & $4.2^{\mathrm{SD}}$ & 12.5 & $\mathrm{OA}$ & $\mathrm{Sz}$ & $\mathrm{Mhy}$ & $\mathrm{S}$ & Pal \\
\hline Pterostichus niger (Schaller) & 3 & $2.1^{\mathrm{SD}}$ & 8.3 & $\mathrm{~F}$ & $\mathrm{Lz}$ & $\mathrm{Mhy}$ & $\mathrm{A}$ & $\mathrm{ES}$ \\
\hline Pterostichus melanarius (Ill.) & 4 & $3.0^{\mathrm{SD}}$ & 8.3 & $\mathrm{Eu}$ & $\mathrm{Lz}$ & $\mathrm{Mhy}$ & $\mathrm{S}$ & $\mathrm{ES}$ \\
\hline Anisodactylus signatus (Panz.) & 5 & $3.5^{\mathrm{SD}}$ & 16.6 & $\mathrm{~F}$ & $\mathrm{Sz}$ & Mhy & $\mathrm{S}$ & $\mathrm{ES}$ \\
\hline Dolichus halensis (Schall.) & 3 & $2.1^{\mathrm{SD}}$ & 8.3 & $\mathrm{OA}$ & $\mathrm{Sz}$ & Mhy & Pal \\
\hline Poecilus cupreus (L.) & 3 & $2.1^{\mathrm{SD}}$ & 8.3 & $\mathrm{Eu}$ & $\mathrm{Sz}$ & Mhy & $\mathrm{S}$ & Pal \\
\hline Harpalus sp. & 1 & $0.7^{\mathrm{SR}}$ & 4.1 & & $\mathrm{~Hz}$ & & & \\
\hline Carabus ulrichii (Germ.) & 2 & $1.4^{\mathrm{R}}$ & 8.3 & $\mathrm{~F}$ & $\mathrm{Lz}$ & $\mathrm{Mhy}$ & $\mathrm{S}$ & $\mathrm{ES}$ \\
\hline Diachromus germanus (L.) & 1 & $0.7 \mathrm{~S}^{\mathrm{R}}$ & 4.1 & $\mathrm{~F}$ & $\mathrm{~Hz}$ & $\mathrm{M}$ & $\mathrm{S}$ & $\mathrm{ES}$ \\
\hline Harpalus affinis (Schrank) & 1 & $0.7 \mathrm{~S}^{\mathrm{R}}$ & 4.1 & $\mathrm{OA}$ & $\mathrm{Hz}$ & Mhy & $\mathrm{S}$ & Pal \\
\hline Zabrus tenebrioides Goeze & 1 & $0.7 \mathrm{~S}^{\mathrm{R}}$ & 4.1 & $\mathrm{OA}$ & $\mathrm{Sz}$ & Mhy & $\mathrm{A}$ & Pal \\
\hline Anchomenus dorsalis (Pont.) & 1 & $0.7 \mathrm{~S}^{\mathrm{R}}$ & 4.1 & $\mathrm{Eu}$ & $\mathrm{Sz}$ & Mhy & $\mathrm{S}$ & Pal \\
\hline Carabus granulatus (L.) & 1 & $0.7 \mathrm{~S}^{\mathrm{R}}$ & 4.1 & $\mathrm{Eu}$ & $\mathrm{Lz}$ & $\mathrm{M}$ & $\mathrm{S}$ & $\mathrm{ES}$ \\
\hline Total & 142 & 100 & & & & & & \\
\hline
\end{tabular}

Domination-ED-eudominants, D- dominants, SD- subdominants, R- recedents SR- subrecedents;

H.p.-Habitat preference : F-forest, OA- open area, Eu-eurytopic;

F.d. -Feeding demands: Lz- large zoophage; $\mathrm{Sz}$ - small zoophage ; $\mathrm{Hz}$ - hemizoophage;

P.h. - Preferred humidity: Mhy- Mesohygrophillic, $\mathrm{M}=$ mesophillic;

T.d.- Type of development: A autumn; S spring;

Z. -zoogeographical: Pal - Palaearctic; ES - Euro-Siberian, Ear - Euroarctic

The high similarity between sites I and III (with IPM) can be explained by the fact that in the surroundings of these orchards dense plant cover of herbaceous plants, shrubs and trees created specific diverse habitats for carabid beetles (Table 1), whereas the poor vegetation around orchard II limited the number of carabids in this site. The high similarity between the places with the most varied vegetation and ecological orchard suggests that not only the management system but also the surrounding orchard play a major role in the occurrence of ground-dwelling arthropods

The trophic structure of the collected beetles showed 9 species of small zoophages, 5 species of large zoophages, and 3 species and 4 genera of hemizoophages (Table 2).

Statistically significant differences were found between the number of species and between the specimens of different feeding types occurring on the different sites. The largest numbers of species of small zoophages were recorded on sites II (5) and IV (6), of large zoophages on sites III (3) and IV (4), and of hemizoophages on site IV ( 3 species and 2 genera) (Table 2).

In terms of the number of specimens, the hemizoophages represented by the species $H$. rufipes, H. affinis, D. germanus and the genera Amara, Ophonus and Harpalus constituted the dominant group among the collected Carabidae - the highest number was found in the ecological orchard (site IV) - 113 individuals, with the smallest number found on site II - 39 beetles (Fig. 2). On site I, this group constituted $85 \%$ of all the collected beetles - the highest percentage out of all the sites.

There were no significant differences between the small and large zoophages occurring on each site except for site III, where large zoophages were more numerous ( $21 \%$ of all the beetles caught). Statistically significant differences were found between the number of large

Table 3. Species richness of Carabidae on different sites during 2012-2013.

\begin{tabular}{|c|c|c|c|c|c|c|c|c|c|c|c|c|}
\hline & \multicolumn{3}{|c|}{ Site I } & \multicolumn{3}{c|}{ Site II } & \multicolumn{3}{c|}{ Site III } & \multicolumn{3}{c|}{ Site IV } \\
\cline { 2 - 46 } & 2012 & 2013 & Total & 2012 & 2013 & Total & 2012 & 2013 & Total & 2012 & 2013 & Total \\
\hline Number of species & 6 & 5 & 8 & 4 & 6 & 7 & 7 & 6 & 9 & 10 & 9 & 13 \\
\hline Species richness & 3.1 & 2.6 & 3.7 & 2.0 & 3.7 & 3.5 & 3.6 & 3.4 & 4.3 & 4.7 & 5.1 & 5.8 \\
\hline
\end{tabular}




\begin{tabular}{|c|c|c|c|c|}
\hline & Site I & Site II & Site III & Site IV \\
\hline Site I & $\mathrm{x}$ & & & \\
\hline Site II & 37.5 & $\mathrm{x}$ & & \\
\hline Site III & 57.1 & 33.3 & $\mathrm{x}$ & \\
\hline Site IV & 52.9 & 33.3 & 36.8 & $\mathrm{x}$ \\
\hline
\end{tabular}

Fig. 1. Similarity of carabid associations calculated from Marczewski and Steinhaus (Czekanowski's diagram).

zoophages occurring on sites II and III - the largest amount of these beetles was recorded on site III (17 specimens). There were no significant differences in the number of small zoophages between the orchards with IPM (site I, II, III); the largest amount was noted on the ecological site (IV) - 19 beetles, but this was only $13.4 \%$ of all the collected beetles (Fig. 2).

The recorded species belonged to: forest species (7 species - 41.1\%), open-habitat species (6 species - 35.3\%), and eurytopic species (4 species - 23.5\%). Among the zoogeographical groups, the largest group (58.8\%) was composed of Palaearctic species, and a slightly smaller group (35.3\%) of Euro-Siberian species. The remaining Euroarctic species were represented by one species $N$. brevicollis (5.8\%) (Table 2).

In terms of hygro preference (humidity), the dominance of mesohygrophillic species was noted, whereas in terms of the type of development, the spring species dominated (Table 2).

\section{Discussion}

During the study, 367 individuals of the Carabidae family, representing 15 genera and 17 species, were caught. Most of them are common in southeastern Poland [14]; however, the study also showed the presence of the very rare species D. germanus. Dominated hemizoophagous species were represented by the species $H$. rufipes, $H$. affinis and $D$. germanus

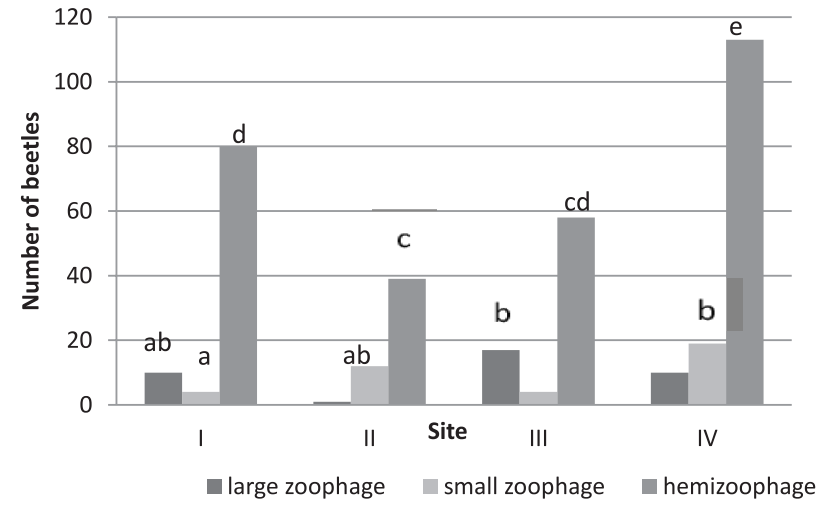

Fig. 2. Occurrence of carabids of different feeding types on different sites (2012-13). and the genera Amara, Ophonus and Harpalus. Similar carabidae assemblages are reported by Kosewska [15], who noticed mainly hemizoophages and medium zoophages on the studied plantations.

H. rufipes was the dominant species on the examined sites (both in the orchards with integrated and ecological production). According to Kosewska and Nijak [16], $H$. rufipes also dominated in organic and integratedmanagement cultivation system of potato. Nietupski [17] and Luff [18] had noted the dominance of this species in an orchard with integrated production as well as in the cultivation of strawberries. According to Lochard et al. [1], Harpalus affinis and $H$. distinguendus were the best biocontrol agents of fruit fly populations in spring. Luff [18] found out that the genus Harpalus, feeding on weed seeds, can significantly reduce them in crops. This is very important, especially in the ecological system of crop cultivation, where the use of herbicides is prohibited [19]. Also Brygadyrenko et al. [20] observed that the Harpalus sp. consumed a wide variety of seed species, which were one of the main sources of energy for carabids of this particular species.

The differentiation in species composition as well as the abundance of beetles occurring on the different sites depended on the type and diversity of the examined habitats. The highest species richness and abundance of the Carabidae was found in the ecological apple orchard surrounded by walnut trees and herbaceous vegetation. This demonstrated the favourable habitat conditions prevailing at site IV, where no chemical treatments were used. This kind of management can improve the condition of these beneficial organisms.

An interesting aspect was the predatory/ hemizoophages species ratio found in the orchards. The higher ratio of zoophages to hemizoophages in the ecological orchard showed that the environment provides a good source of prey. The presence of predator species suggested that biological control is active in the ecological orchard. The slightly lower ratio of zoophages/hemizoophages in the IPM orchard where chemical treatment was applied suggested that the potential prey was eliminated and indicated a limited attraction of predatory beetles who might otherwise feed on apple tree pests.

The species composition and abundance of beetles occurring on the different sites depended on the different production systems, type of the examined habitats as well as the degree of differentiation of the surrounding plants. It has been stated that the highest species richness and abundance of the Carabidae was noted in the ecological orchard (site IV). This was most probably a consequence of the method of production, where no chemical treatments were used, which thus created favourable conditions for the development of the Carabidae. In contrast to the organic orchard, in which the species composition of the Carabidae was determined by the environment, the factors that significantly affected the Carabidae populations in 
the IPM orchards were pesticide treatments, although the presence of refuge sites in the neighbourhood contributed to the increase in the species richness of the Carabidae.

As has been pointed out by several authors [11, 12], the use of insecticides in apple orchards adversely affects ground beetle species richness and abundance. Nietupski [17] found that among the pesticides used in IFP orchards, herbicides negatively affected the catchability of carabids. Also, Simon et al. [9] noted the negative effect of pesticides on ground-living arthropods. Sacdej et al. [21] pointed out that the most significant factor affecting carabids consisted in type of soil management and fertilization. Significantly more carabid individuals were found in the fallows compared to the experimental plots.

The presence of large zoophages and forest species on the examined sites is evidence of their good ecological status. A large amount of open-area species demonstrates the migratory ability of ground beetles, which can find shelter in bushes and trees surrounding orchards [22-24]. Beetles are quite mobile insects, and as they are considered to travel within a $450 \mathrm{~m}$ radius, the surrounding area is quite important for them. The surroundings, including hedges, field margins, influences on the beetle population thus providing shelter and an alternative food source for them. Hanson et al. [23] suggested that the dispersal ability of ground beetles enables them to compensate for local management intensities. The presence of zoophagous carabids in crops is highly desirable due to their role in pest control [1-4]. Carabids play a large role in control of pests in orchard systems, particularly as predators of aphids - especially those that fall on the ground, but some species, such as Anchomenus dorsalis, is attracted by honeydew and can climb trees to reach their prey. They are effective biological control agents, able to respond quickly to wherever a pest infestation occurs [22].

Some studies have compared the effects of chemical and ecological management in different crops. Winqvist et al. [4] noted that as farm scale intensity increased, overall abundance of Carabidae decreased. Authors observed that total species richness was not affected by yield, whereas phytophagous and omnivorous species were less abundant on conventional farms. In contrast, Melnychuk et al. [25], studying the occurrence of carabids in forage grain, found no significant differences in species diversity or abundance between different farming systems. Hanson et al. [23], working on ground beetles in fields with different agricultural land use, found out that increasing management intensity reduces the average body size of carabids and the proportion of mixed feeders. Also, Kosewska [15], studying the effect of plant protection treatments on the occurrence of Carabidae beetles, noted the negative effect of the application of plant protection chemicals - especially herbicides and insecticides - on the occurrence of most Carabidae species.
The presence of refuge places contributes to an increase in the species richness of the Carabidae [22, 24]. Both the cultivation system and plant species influence the abundance and diversity of ground beetles. It confirms the biocenotic rule according to which the diversity of habitats is accompanied by the increase in the number of species, often occurring as recedents and subrecedents contributing to the preservation of biodiversity. Okrutniak et al. [26] found out that higher heterogeneity of surroundings provides more diverse places for the development of a much higher number of carabid species than homogeneous sites. According to authors, dense vegetation increases humidity, creating the microclimate favorable for especially mesohydrophilic carabid species. According to other authors, the diversity of the Carabidae is affected by the type of agrocenosis, cultivation system, and the diversification of the landscape around the studied area. Plants surrounding the fields could be a place of refuge and a source of food for carabids, resulting in the proliferation of the beetles [27]. The present study showed how the orchard management system and differentiation of plants surrounding orchards were important factors in protecting ground beetles - natural enemies of many pests - in apple orchards, and how the biodiversity of this group might be enhanced with a specific practice.

\section{Conclusions}

Organic and integrated systems of managing apple orchards had a different effect on carabid communities. The use of plant protection chemicals had a negative impact on the assemblages of the Carabidae as the number and biodiversity of beetles on site where no pesticides were used were higher than on other sites. Among the IPM orchards, the largest fauna of the carabids was in the orchard with the most diverse plant habitat: herbaceous plants, shrubs and trees in its neighbourhood. The presence of refuge areas and their vegetational diversity contributed to the increase in the species richness of the Carabidae.

The ecological structure of an orchard should be created in such a way as to provide favourable conditions for the protection and proliferation of the Carabidae in their natural habitat.

\section{Acknowledgements}

The authors thank farm owners Tadeusz Szeliga and Marian Szeliga from Specialist Orchard Farm in Żurawica near Przemyśl for allowing our work in the orchards.

We are grateful dr inż. Tomasz Olbrycht from the Faculty of Biology and Agriculture University of Rzeszów for help in identifying some Carabidae species. 


\section{Funding}

This research was supported by the Ministry of Science and Higher Education of Poland as part of the statutory activities of the Department of Plant Protection, University of Agriculture, DS-3500/WBiO/.

\section{Conflict of Interest}

The authors declare no conflict of interest.

\section{References}

1. LOCHARD G, MOUTON S, GARCIN A. Potential of ground arthropods as predators of larvae and pupae of and fruit flies (Diptera and Tephritidae). Integrated Plant Protection in Stone Fruit IOBC/wprs Bulletin 3, 83, 2008.

2. MONZÓ C., SABATER-MUÑOZ B., URBANEJA A., CASTAÑERA P. The ground beetle Pseudophonus rufipes revealed as predator of Ceratitis capitata in citrus orchards. Biological Control 56, 17, 2011.

3. ALBERTINI A, PIZZOLOTTO R, PETACCHI R. Carabid patterns in olive orchards and woody semi-natural habitats: first implications for conservation biological control against Bactrocera oleae. BioControl 62, 71, 2017.

4. WINQVIST C., BENGTSSON J., ÖCKINGER E., AAVIK T., BERENDSE F., CLEMENT L. ET AL. Species-traits influence ground beetle responses to farm and landscape level agricultural intensification in Europe. Journal of Insect Conservation 18, 837, 2014.

5. PIZZOLOTTO R., MAZZEI A., BONACCI T., SCALERCIO S., IANNOTTA N., BRANDMAYR P. Ground beetles in Mediterranean olive agroecosystems: Their significance and functional role as bioindicators (Coleoptera, Carabidae).PLoS ONE 13 (3) e 0194551, 2018.

6. EYRE M., MCMILLAN S., CRITCHLEY C. Ground beetles (Coleoptera, Carabidae) as indicators of change and pattern in the agroecosystem: Longer surveys improve understanding. Ecological Indicators 68, 82, 2016.

7. BURGIO G., CAMPANELLI G., LETEO F., RAMILLI F., DEPALO L., FABBRI R., ET AL. Ecological sustainability of an organic four-year vegetable rotation system: Carabids and other soil arthropods as bioindicators. Agroecology and Sustainable Food Systems 39, 295, 2015.

8. SĄDEJ W., KOSEWSKA A., SĄDEJ W., NIETUPSKI M. Effects of fertilizer and land use type on soil properties and ground beetle communities. Bulletin of Insectology, 65 (2), 239, 2012.

9. SIMON S., BOUVIER J-CH, DEBRAS J-F, SAUPHANOR B. Biodiversity and pest management in orchard systems. Agron. Sustain. Develop. 30, 139, 2010.

10. HEDDE M., MAZZIA C., DECAËNS T., NAHMANI J., PEY B., THÉNARD J., ET AL. Orchard management influences both functional and taxonomic ground beetle (Coleoptera, Carabidae) diversity in South-East France. Applied Soil Ecology 88, 26, 2015.

11. EPSTEIN D.L., ZACS R.S., BRUNNER J.F. GUT L., BROWN J.J. Ground beetle activity in apple orchards under reduced pesticide management regimes. Biol. Control. 21, 2, 97, 2001.
12. FUNAYAMA K. Influence of pest control pressure on occurrence of ground beetles (Coleoptera: Carabidae) in apple orchards. Appl. Entomol. Zool. 46, 1, 103, 2011.

13. ALEKSANDROWICZ O., PAKUŁA B. GÓRA S. Species composition and structure of Carabidae (Coleoptera) assembly in cultivation of winter oilseed rape in Osowo (Pomorskie voivoleship). Prog. Plant Prot. 49, 4, 1941, 2009.

14. STACHOWIAK M. Checklist Carabidae (Coleoptera) of Poland. 2008. http://www.entomo.pl /coleoptera/carabidae/ index.php, accessed: 17.02.2016.

15. KOSEWSKA A. Effect of plant protection treatments on the occurrence of ground beetles (Col. Carabidae) in selected plant plantations. Progress in Plant Protection, 52 (3), 529, 2012.

16. KOSEWSKA A., NIJAK K. Structure analysis of carabid beetles (Col., Carabidae) assemblages in integrated and organic potato management Short communication. Biuletyn Instytutu Hodowli i Aklimatyzacji Roślin. 265, 157, 2012.

17. NIETUPSKI M. Ground beetles (Coleoptera: Carabidae) occurring in apple orchards under different production systems. Prog. Plant Prot. 52, 2, 360, 2012.

18. LUFF M.L. The biology of the ground beetle Harpalus rufipes of a strawberry field in Northumberland. Ann. Appl. Biol. 94, 153, 1980.

19. KULKARNI S.S., DOSDALL L.M., WILLENBORG CH.J. The role of ground beetles (Coleoptera: Carabidae) in weed seed consumption: A Review, Weed Science 63, (2), 335, 2014.

20. BRYGADYRENKO V.V., RESHETNIAK D.Y. Trophic preferences of Harpalus rufipes (Coleoptera, Carabidae) with regard to seeds of agricultural crops in conditions of laboratory experiment. Baltic J. Coleopterol. 14 (2), 1407, 2014.

21. SĄDEJ W., KOSEWSKA A., SĄDEJ W., NIETUPSKI M. Effects of fertilizer and land-use type on soil properties and ground beetle communities. Bulletin of Insectology, 65 (2), 239, 2012.

22. HOLLAND J.M., BIRKETT T., SOUTHWAY S. Contrasting the farm-scale spatio-temporal dynamics of boundary and field overwintering predatory beetles in arable crops. Biol. Control 54, 19, 2009.

23. HANSON H., PALMU E., BIRKHOFER K., SMITH H., HEDLUND K. Agricultural Land Use Determines the Trait Composition of Ground Beetle Communities. PLoS ONE 11 (1), e 0146329, 2016.

24. KONIECZNA K., OLBRYCHT T., WOJCIECHOWICZŻYTKO E., WILK E. Effect of agrotechnical measures on the abundance of ground beetles (Coleoptera: Carabidae) in selected cultivations. Episteme. 26/II, 357, 2015.

25. MELNYCHUCK N.A., OLFERT O., YOUNGS B., GILLOT C. Abundance and diversity of Carabidae (Coleoptera) in different farming system. Agricult. Ecosyst. Environ. 95, 69, 2003.

26. OKRUTNIAK M., GRZEŚ I.M., BONCZAR Z. Species diversity of carabid beetles and ants of two reclaimed tailing ponds. Pol. J. Environ. Stud. 27 (6), 2703, 2018.

27. WEIBULL A.-C., ÖSTMAN Ö., GRANQVIST A. Species richness in agroecosystems: the effect of landscape, habitat and farm management. Biodivers. Conserv. 12, 1335, 2003. 